\title{
FORMULASI TEH HERBA MANIS (TEH HIJAU-STEVIA-HERBA): ORGANOLEPTIK, ANTIOKSIDAN DAN TOTAL KALORI
}

\author{
FORMULATION OF SWEET HERB TEA ( GREEN TEA-STEVIA-HERB): \\ ORGANOLEPTIC, ANTIOXIDANT AND TOTAL CALORIE
}

\author{
Setyaningrum Ariviani ${ }^{1)}$, Dwi Ishartani ${ }^{1)}$ \\ ${ }^{1)}$ Staf Pengajar Jurusan Ilmu dan Teknologi Pangan,Fakultas Pertanian,Universitas Sebelas Maret, Surakarta
}

\begin{abstract}
The objective of this research were to formulate sweet herb tea (green tea-stevia-herb) base on consumer preference and to determine their antioxidant and total calorie content. Stevia was used as sweetener because of the antioxidant capacity. Herb that were used consist of ginger, clove and cinnamon because of their antioxidant capability related to phenol content and as cultural commonly used in beverage.

Sweet herbal tea that preferable to consumer base on color, flavor, taste and appareance of brewed tea, contain of green tea : stevia (65:35), herb 15\% of green tea-stevia mix with more than one kind of herb. The sweet herbal tea showed high antioxidant cantent, i.e. 157.73 - $162.67 \mathrm{mg}$ fenol/serving. Total Calorie content of tested teas were lower than that of sugar, i.e. 30 - $152 \mathrm{kal}$ serving. Result of this research showed that sweet herb tea have future chance to develop as functional beverage base on local sources.
\end{abstract}

Keywords: antioxidant,calorie, formulation, sweet herb tea

\begin{abstract}
Abstrak
Penelitian ini bertujuan untuk formulasi teh herba manis (teh hijau-stevia-herba) yang disukai konsumen dan menentukan kadar antioksidan dan kalorinya. Sebagai pemanis digunakan stevia karena diketahui memiliki kapasitas antioksidan. Herba yang digunakan terdiri dari jahe, kayu manis dan cengkeh karena kandungan senyawa fenolik yang dapat berperan sebagai antioksidan dan secara kultural biasa digunakan dalam minuman.

Teh herba manis yang disukai konsumen berdasarkan warna, aroma, rasa dan kenampakan keseluruhan seduhan teh adalah formula dengan proporsi teh hijau : stevia 65: 35, proporsi herba 15\% terhadap campuran teh hijau-stevia, menggunakan lebih dari satu macam herba. Teh herba manis ini memperlihatkan kadar antioksidan yang tinggi, yaitu $157.73-162.67 \mathrm{mg}$ fenol/ saji. Total kalori teh yang diuji jauh lebih rendah dibandingkan gula, yaitu sebesar $30-152 \mathrm{kal} / \mathrm{saji}$. Hasil penelitian ini memperlihatkan bahwa teh herba manis ini cukup prospektif untuk dikembangkan sebagai minuman fungsional berbasis bahan lokal.
\end{abstract}

Kata kunci: antioksidan, kalori, formulasi, teh herba manis

\section{PENDAHULUAN}

Dewasa ini penyakit-penyakit degeneratif menjadi salah satu momok bagi masyarakat. Penyakit degeneratif menyangkut oksidasi pada tingkat subseluler yang menghasilkan senyawa radikal yang akan menyerang lipid penyusun membran sel, DNA inti sel, dan protein (Astuti, 1995). Keberadaan senyawa radikal dalam tubuh sebagai akibat proses fisiologis dan faktor luar akan diimbangi oleh mekanisme pertahanan endogen dengan menggunakan senyawa yang mempunyai kemampuan sebagai anti radikal bebas atau antioksidan. Namun demikian, efisiensi penghilangan senyawa radikal tidak pernah mencapai $100 \%$. Oleh karena itu penting meningkatkan konsumsi antioksidan alami dari bahan pangan (Muchtadi, 2000). Beberapa bahan makanan yang kaya akan senyawa antioksidan alami diantaranya teh hijau dan herba seperti jahe, kayu manis dan cengkeh.

Minum teh telah menjadi kebiasaan sehari-hari bagi warga Asia. Teh hijau (Camellia sinensis L. Kuntz), merupakan sumber polifenol seperti epigallocatechingallate (EGCG), epigallocatechin (EGC), epicatechingallate (ECG), dan epicatechin (EC) yang memiliki kapasitas antioksidan tinggi dan merupakan komponen bioaktif yang memiliki manfaat dalam bidang kesehatan seperti antidiabetik, neuroprotective, antiviral, antimalarial, hepatoprotective, dan cardioprotective, mengurangi resiko penyakit jantung koroner, stroke dan kanker. Selain itu beberapa penelitian terdahulu juga telah melaporkan bahwa komponen polifenol dalam teh hijau merupakan antioksidan yang baik untuk 
melawan peroksidasi lipid dalam membran fosfolipid bilayer, dalam sistem biologis, memiliki kemampuan melawan tumorigenesis dan kerusakan DNA, disamping menurunkan kadar kolesterol serum, menghambat hipertensi, mutagenesis dan tumourigenesis in vitro maupun invivo (Lin et al., 2008). Beberapa penelitian memperlihatkan bahwa kapasitas antioksidan teh hijau memiliki korelasi yang lebih tinggi dengan komponen fenolik dibanding vitamin C, tokoferol atau beta karoten (Lee et al., 2007).

Teh hijau juga memberikan efek saturasi yang membuat peminumnya seolaholah kenyang, sehingga mengurangi asupan bahan pangan lainnya. Khasiat lainnya adalah membunuh bakteri dan mendukung pertumbuhan flora saluran pencernaan yang menguntungkan.

Selama ini teh hijau biasa dikonsumsi sebagai minuman obat dan minuman pelangsing. Oleh karena itu, teh hijau lebih sering dikonsumsi dalam bentuk seduhan pahit untuk menghindari asupan kalori dari gula. Rasa pahit dari teh hijau inilah yang sering menyebabkan konsumen enggan mengkonsumsinya. Dalam penelitian ini, akan diformulasikan teh hijau manis dengan penggunaan stevia sebagai pemanis dan sebagai penambah cita rasa ditambahkan herba yang meliputi jahe, kayu manis dan cengkeh.

Ekstrak stevia dilaporkan memperlihatkan beberapa manfaat bagi kesehatan manusia, seperti antihipertensi, antihiperglikemik, dan aktivitas anti-human rotavirus (Chan et al., 2000; Lee et al., 2001, Jeppesen et al., 2000; Das et al., 1992 dalam Tadhani et al., 2007). Tadhani et al. (2007) meneliti tentang aktivitas antioksidan daun dan callus Stevia rebaudiana melaporkan bahwa daun stevia kering mengandung komponen fenolik total sebesar $25.18 \mathrm{mg} / \mathrm{g}$ daun (dalam berat kering), senyawa flavonoid $21.73 \mathrm{mg} / \mathrm{g}$ (dalam berat kering), dan kapasitas antioksidan total (TAC) berkisar antara 9.66 - $38.24 \mathrm{mg}$ eq untuk ekstrak dalam air and 11.03 - $36.40 \mathrm{mg}$ eq untuk ekstrak dalam metanol.

Winston (1997) melaporkan bahwa jahe mengandung komponen fenolik yang dikenal sebagai gingerol dan diarilhaptanoid yang mempunyai kapasitas antioksidan lebih besar dibanding vitamin E (alfa tokoferol). Total fenol dalam ekstrak etanol jahe mencapai $870.1 \mathrm{mg} / \mathrm{g}$ ekstrak kering (Stoilova et al., 2007).

Kayu manis merupakan flavouring ingredient yang digunakan secara luas pada produk pangan. Anderson and Broadhurst (2004), Murcia et al. (2004) melaporkan bahwa kayu manis mempunyai beberapa manfaat bagi kesehatan, seperti aktivitas antimikrobia, pengendalian glucose intolerance dan diabetes, penghambatan proliferasi sel kanker. Tamaino et al. (2005) menyatakan bahwa minyak atsiri kayu manis memiliki beberapa komponen fenolik seperti eugenol, cinamic aldehid dan beta caryophyllene yang berpotensi sebagai antioksidan. Ekstrak kayu manis memperlihatkan kemampuan menurunkan peroksidasi lipid dalam sistem beta karotenasam linoleat, dan efek penghambatannya setara dengan BHT pada konsentrasi 100 ppm. Ekstrak kayu manis juga memperlihatkan kemampuan proteksi terhadap peroksidasi lipid dalam liposom yang diinduksi irradiasi dan memiliki kemampuan mengquenching radikal hidroksi dan hydrogen peroksida (Murcia et al., 2004).

Ekstrak senyawa aroma cengkeh terutama tersusun oleh senyawa fenolik seperti eugenol, eugenyl asetat dan benzyl alcohol yang mampu menghambat pembentukan malonaldehid minyak hati ikan cod karena kapasitas antioksidannya yang sebanding dengan alfa tokoferol (Lee and Shibamoto, 2001). Ilham et al. (2004) melaporkan bahwa ekstrak clove (cengkeh) memiliki kapasitas antioksidan melalui beberapa mekanisme, yaitu mendonorkan hidrogen, mengchelat logam, dan efektif sebagai penangkap hidrogen peroksida, superoksida dan radikal bebas. Komponen yang bertanggung jawab terhadap aktivitas antioksidan ini adalah senyawa fenolik.

Penelitian ini bertujuan untuk menentukan formula teh herba manis yang disukai oleh konsumen dan selanjutnya ditentukan kadar antioksidan dan kalorinya. Teh herba manis dibuat dalam bentuk teh 
celup (siap saji) untuk memudahkan dalam penggunaannya. Antioksidan dalam teh herba manis ditentukan berdasarkan kadar total fenol dalam bahan, hal ini dikarenakan senyawa antioksidan dalam teh hijau, kayu manis, cengkeh maupun stevia merupakan senyawa fenolik. Kadar kalori teh ditentukan dengan bomb kalorimeter.

\section{BAHAN DAN METODE}

\section{Bahan}

Bahan yang digunakan dalam penelitian ini meliputi teh hijau kering kualitas jikeng diperoleh dari Perkebunan Teh Kemuning, daun stevia segar yang diperoleh dari petani di Tawangmangu, kantong polistiren dan tali yang dibeli dari toko Tekun Jaya di Yogyakarta, jahe, kayu manis dan cengkeh diperoleh dari pasar Gedhe Surakarta, aquadest, kertas saring, filler dan reagen kimia: follin-ciocalteu, $\mathrm{NaOH}, \quad \mathrm{Na}_{2} \mathrm{CO}_{3}$, larutan standar fenol murni diperoleh dari Lab Kimia Biokimia Fakultas Teknologi Pertanian UGM.

\section{Metode}

\section{Persiapan sampel}

Daun stevia disortasi untuk memisahkan bagian tangkai dan bagian yang busuk serta membuang rumput yang terikut. Setelah dicuci, daun stevia dikeringkan menggunakan pengering matahari sampai dengan daun bisa dipatahkan. Teh hijau kering dan daun stevia kering masing-masing dihancurkan sampai lolos ayakan 8 mesh. Rimpang jahe dipotong-potong, dikeringkan sampai kadar air 8-10\%, digiling dan diayak hingga lolos ayakan 30 mesh. Cengkeh dan kayu manis masing-masing digiling dan diayak hingga lolos ayakan 30 mesh.

Formulasi teh herba manis (teh hijaustevia-herba):

* Variasi proporsi teh hijau: stevia :

$$
\begin{aligned}
& \mathrm{S}_{1}=25: 75 ; \quad \mathrm{S}_{2}=30: 70 ; \\
& \mathrm{S}_{3}=35: 65 ; \quad \mathrm{S}_{4}=40: 60 \\
& \text { Variasi proporsi herba: } \\
& \mathrm{H}_{1}=\text { Herba } 5 \% ; \\
& \mathrm{H}_{2}=\text { Herba } 10 \% ; \\
& \mathrm{H}_{3}=\text { Herba } 15 \%
\end{aligned}
$$

- Variasi komposisi herba:

$\mathrm{P}_{1}=$ jahe $:$ kayu manis $:$ cengkeh $=1: 0: 0$

$\mathrm{P}_{2}=$ jahe $:$ kayu manis $:$ cengkeh $=0: 1: 0$

$\mathrm{P}_{3}=$ jahe : kayu manis : cengkeh $=0: 0: 1$

$\mathrm{P}_{4}=$ jahe $:$ kayu manis $:$ cengkeh $=1: 1: 0$

$\mathrm{P}_{5}=$ jahe $:$ kayu manis $:$ cengkeh $=1: 0: 1$

$\mathrm{P}_{6}=$ jahe $:$ kayu manis $:$ cengkeh $=0: 1: 1$

$\mathrm{P}_{7}=$ jahe $:$ kayu manis $:$ cengkeh $=1: 1: 1$

$\mathrm{P}_{8}=$ jahe $:$ kayu manis $:$ cengkeh $=2: 1: 1$

$\mathrm{P}_{9}=$ jahe $:$ kayu manis $:$ cengkeh $=1: 2: 1$

$\mathrm{P}_{10}=$ jahe $:$ kayu manis $:$ cengkeh $=1: 1: 2$

Pemilihan formula didasarkan pada kesukaan konsumen terhadap warna, aroma, rasa dan kenampakan keseluruhan yang dianalisis menggunakan Uji Hedonik dengan teknik skoring menggunakan 20 panelis. Dipilih lima formula terbaik untuk ditentukan kalori dan antioksidannya.

Analisis antioksidan dengan penentuan total fenol (Senter, dkk, 1989 modifikasi dengan metode plumer, 1971).

Analisis dilakukan dalam 3 ulangan. Analisis total fenol dilakukan dengan ekstraksi senyawa fenol sampel teh herba terpilih (lima formula terbaik) dengan perebusan. Ekstrak yang diperoleh diambil $1 \mathrm{ml}$ selanjutnya ditambah dengan $5 \mathrm{ml}$ lart $2 \% \mathrm{Na}_{2} \mathrm{CO}_{3}$ dalam $\mathrm{NaOH} 0.5 \mathrm{~N}$, diinkbasi suhu kamar selama 10 menit, direaksikan dengan $0.5 \mathrm{ml}$ lart folinciocalteu (1:2), divortek, diinkubasi suhu kamar selama 30 menit dan ditera absorbansinya pada panjang gelombang 750 $\mathrm{nm}$. Total fenol ditentukan berdasarkan kurva standar larutan fenol murni. Total fenol dinyatakan dalam $\mathrm{mg} / \mathrm{saji}$ (mg/kantong teh celup)

\section{Analisis kalori dengan bomb kalorimeter}

Analisis kalori dilakukan dengan ekstraksi teh celup menggunakan air mendidih selama 3 menit, ekstrak yang diperoleh dievaporasi hingga diperoleh pasta kental. Selanjutnya ditambahkan filler dan dikeringkan dengan oven pengering. Terakhir diuji dengan bomb kalorimeter. Sebagai kontrol digunakan filler. Hasilnya dinyatakan dalam kal/saji (kal/seduhan dari 1 kantong teh celup).

\footnotetext{
Analisis data

Data dianalisis menggunakan ANOVA dan untuk menguji perbedaan antar perlakuan dilakukan uji DMRT
} 


\section{HASIL DAN PEMBAHASAN}

\section{Formulasi Teh Herba Manis Rendah Kalori}

Selama ini teh hijau biasa dikonsumsi sebagai minuman obat dan minuman pelangsing. Oleh karena itu, teh hijau lebih sering dikonsumsi dalam bentuk seduhan pahit untuk menghindari asupan kalori dari gula. Rasa pahit dari teh hijau inilah yang sering menyebabkan konsumen enggan mengkonsumsinya. Dalam penelitian ini teh hijau diformulasi menjadi teh herba manis dengan penggunaan stevia sebagai pemanis dan sebagai penambah cita rasa ditambahkan herba yang meliputi jahe, kayu manis dan cengkeh.

Pemilihan stevia sebagai pemanis didasarkan pada beberapa alasan, antara lain: stevia sebagai pemanis dinyatakan aman dan tanpa kalori, stevia mengandung senyawa stesviosida yang memiliki tingkat kemanisan 300 x sukrosa (Gates, 2000). Tadhani et al. (2007) yang meneliti tentang aktivitas antioksidan daun dan callus Stevia rebaudiana melaporkan bahwa daun stevia kering mengandung komponen fenolik total sebesar $25.18 \mathrm{mg} / \mathrm{g}$ daun (dalam berat kering), senyawa flavonoid $21.73 \mathrm{mg} / \mathrm{g}$ (dalam berat kering), dan kapasitas antioksidan total (TAC) ekstrak air berkisar antara 9.66 - $38.24 \mathrm{mg}$ eq. Selain itu, ekstrak stevia dilaporkan memperlihatkan beberapa manfaat bagi kesehatan manusia, seperti antihipertensi, antihiperglikemik, dan aktivitas anti-human rotavirus (Chan et al., 2000; Lee et al., 2001, Jeppesen et al., 2000; Das et al., 1992 dalam Tadhani et al., 2007).

Jahe, kayu manis dan cengkeh digunakan sebagai herba pada pembuatan teh herba manis ini karena ketiga jenis herba tersebut secara kultural biasa digunakan sebagai penambah cita rasa minuman. Pertimbangan lain karena baik jahe, cengkeh maupun kayu manis diketahui memiliki kapasitas antioksidan terkait dengan komponen fenoliknya (Winston, 1997; Tamaino et al.. 2005; Lee and Shibamoto, 2001). Anderson and Broadhurst (2004), Murcia et al. (2004) melaporkan bahwa kayu manis mempunyai beberapa manfaat bagi kesehatan, seperti aktivitas antimikrobia, pengendalian glucose intolerance dan diabetes, penghambatan proliferasi sel kanker. Ilham et al. (2004) melaporkan bahwa ekstrak clove (cengkeh) memiliki kapasitas antioksidan melalui beberapa mekanisme, yaitu mendonorkan hidrogen, mengchelat logam, dan efektif sebagai penangkap hidrogen peroksida, superoksida dan radikal bebas.

Formulasi teh herba manis pada penelitian ini dilakukan dalam tiga tahap. Tahap pertama adalah penentuan proporsi stevia terhadap teh hijau, terdiri dari 4 taraf yaitu teh hijau: stevia $=(75: 25=\mathrm{S} 1),(70: 30$ $=$ S2), $(65: 35=$ S3) dan $(60: 40=$ S4). Campuran teh hijau (+) stevia ini selanjutnya dimasukkan dalam kantong polistiren @2 gram. Keempat formula (S1, S2, S3 dan S4) ini selanjutnya diseduh dengan teknik penyeduhan sebagai berikut: satu kantong teh celup diseduh dengan penambahan $200 \mathrm{ml}$ air panas (suhu 900C) selama 2 menit, kantung teh celup diangkat, diaduk dan disajikan kepada 25 panelis untuk dilakukan uji hedonik dengan teknik scoring terhadap warna, rasa, aroma dan kenampakan seduhan dengan skor 1-5, 1: Amat sangat suka, 2: sangat suka, 3: suka, 4: agak suka dan 5: tidak suka. Hasil uji sensoris ini selanjutnya dianalisis secara statistik menggunakan ANOVA dilanjutkan DMRT.

Berdasarkan analisis statistik hasil uji sensoris terhadap warna, rasa, aroma dan kenampakan yang telah dilakukan (Tabel 1) diketahui bahwa tingkat kesukaan terhadap aroma, kenampakan dan rasa teh dengan berbagai proporsi stevia tidak beda nyata, tetapi berbeda nyata ditinjau dari kesukaan terhadap warna. Tingkat kesukaan terhadap warna teh formula stevia $30 \%$ paling rendah dibanding yang lain. Berdasarkan tingkat kesukaan terhadap warna inilah dipilih proporsi stevia 35\% untuk tahap formulasi selanjutnya.

Tahap kedua, formulasi untuk penentuan proporsi herba yang ditambahkan. Formula dengan proporsi teh hijau : stevia $(65: 35)$ atau stevia $35 \%$ (S3) ini selanjutnya ditambah dengan herba dengan proporsi $\mathrm{H} 1=5 \%, \mathrm{H} 2=10 \%$ dan $\mathrm{H} 3=15 \%$ terhadap $\mathrm{S} 3$. Formulasi pada tahapan ini dihasilkan 9 formula, yang selanjutnya dikemas dalam 
Tabel 1. Tingkat Kesukaan Teh pada Berbagai Proporsi Stevia

\begin{tabular}{|c|c|c|c|c|}
\hline \multirow{2}{*}{$\begin{array}{c}\text { Formula Teh } \\
\text { (Teh hijau : stevia) }\end{array}$} & \multicolumn{4}{|c|}{ Skor Tingkat Kesukaan ${ }^{*}$} \\
\hline & Warna & Aroma & Rasa & $\begin{array}{c}\text { Kenampakan } \\
\text { keseluruhan }\end{array}$ \\
\hline $75: 25$ (stevia 20\%) & $3.20 \pm 0.616^{b}$ & $3.45 \pm 0.510^{\mathrm{a}}$ & $4.00 \pm 0.510^{\mathrm{a}}$ & $3.50 \pm 0.827^{\mathrm{a}}$ \\
\hline $70: 30($ stevia $30 \%)$ & $3.65 \pm 0.587^{\mathrm{c}}$ & $3.20 \pm 0.410^{\mathrm{a}}$ & $3.95 \pm 0.510^{\mathrm{a}}$ & $3.70 \pm 0.470^{\mathrm{a}}$ \\
\hline $65: 35$ (stevia $35 \%)$ & $2.65 \pm 0.587^{\mathrm{a}}$ & $3.25 \pm 0.786^{\mathrm{a}}$ & $3.35 \pm 1.182^{\mathrm{a}}$ & $3.15 \pm 0.988^{\mathrm{a}}$ \\
\hline $60: 40($ stevia $40 \%)$ & $2.90 \pm 0.718^{\mathrm{ab}}$ & $3.50 \pm 0.607^{\mathrm{a}}$ & $4.80 \pm 0.510^{\mathrm{a}}$ & $3.40 \pm 0.883^{\mathrm{a}}$ \\
\hline
\end{tabular}

Angka yang diikuti huruf yang sama pada kolom yang sama menyatakan tidak berbeda nyata pada $\alpha=0.05$

*)Skor 1: Amat sangat suka, 2: sangat suka, 3: suka, 4: agak suka dan 5: tidak suka

Tabel 2. Tingkat Kesukaan Teh Herba pada Berbagai Proporsi Herba

\begin{tabular}{|c|c|c|c|c|}
\hline \multirow{2}{*}{$\begin{array}{c}\text { Formula Teh } \\
\text { Herba dengan } \\
\text { proporsi } \\
\text { teh: stevia }(65: 35)\end{array}$} & \multicolumn{4}{|c|}{ Skor Tingkat Kesukaan ${ }^{*}$} \\
\hline & Warna & Aroma & Rasa & $\begin{array}{c}\text { Kenampakan } \\
\text { keseluruhan }\end{array}$ \\
\hline Jahe 5\% & $3.10 \pm 0.641^{b}$ & $3.45 \pm 0.605^{\mathrm{ab}}$ & $3.60 \pm 0.821^{\mathrm{a}}$ & $3.30 \pm 0.865^{\mathrm{ab}}$ \\
\hline Jahe $10 \%$ & $3.55 \pm 0.887^{b c}$ & $3.25 \pm 0.550^{\mathrm{ab}}$ & $3.50 \pm 0.761^{\mathrm{a}}$ & $3.35 \pm 0.813^{\mathrm{ab}}$ \\
\hline Jahe $15 \%$ & $4.05 \pm 0.686^{\mathrm{d}}$ & $3.25 \pm 0.851^{\mathrm{ab}}$ & $3.45 \pm 0.826^{\mathrm{a}}$ & $3.75 \pm 0.716^{\mathrm{bc}}$ \\
\hline Kayu manis $5 \%$ & $3.05 \pm 0.605^{\mathrm{b}}$ & $3.65 \pm 0.851^{b}$ & $4.25 \pm 0.716^{\mathrm{b}}$ & $3.95 \pm 0.605^{\mathrm{c}}$ \\
\hline Kayu manis $10 \%$ & $3.30 \pm 0.733^{\mathrm{bc}}$ & $3.65 \pm 0.745^{\mathrm{ab}}$ & $3.90 \pm 1.071^{\mathrm{ab}}$ & $3.80 \pm 0.834^{b c}$ \\
\hline Kayu manis $15 \%$ & $3.70 \pm 0.865^{\mathrm{cd}}$ & $3.75 \pm 0.851^{\mathrm{b}}$ & $4.00 \pm 0.858^{\mathrm{ab}}$ & $3.90 \pm 0.788^{\mathrm{c}}$ \\
\hline Cengkeh $5 \%$ & $3.35 \pm 0.875^{\mathrm{bc}}$ & $3.70 \pm 0.675^{\mathrm{ab}}$ & $3.65 \pm 0.671^{\mathrm{ab}}$ & $3.75 \pm 0.550^{\mathrm{bc}}$ \\
\hline Cengkeh $10 \%$ & $3.10 \pm 0.852^{b}$ & $3.50 \pm 0.761^{\mathrm{ab}}$ & $4.00 \pm 0.973^{\mathrm{ab}}$ & $3.70 \pm 0.733^{b c}$ \\
\hline Cengkeh $15 \%$ & $2.25 \pm 0.550^{\mathrm{a}}$ & $3.20 \pm 0.768^{\mathrm{a}}$ & $3.45 \pm 1.146^{\mathrm{a}}$ & $3.00 \pm 0.858^{\mathrm{a}}$ \\
\hline
\end{tabular}

Angka yang diikuti huruf yang sama pada kolom yang sama menyatakan tidak berbeda nyata pada $\alpha=0.05$ *)Skor 1: Amat sangat suka, 2: sangat suka, 3: suka, 4: agak suka dan 5: tidak suka

kantong polistiren, diseduh dan disajikan pada 20 panelis yang sama dengan tahap 1 dengan teknik seperti pada tahap1. Hasil uji sensoris seperti terlihat pada Tabel 2.

Data dalam Tabel 2 Berdasarkan hasil analisis statistik yang dilakukan (data tidak ditunjukkan) dapat dilihat bahwa proporsi herba berpengaruh terhadap kesukaan panelis terhadap warna, aroma, rasa maupun kenampakan. Berdasarkan warnanya formula cengkeh $15 \%$ (S3C3) paling disukai dibanding formula yang lain. Ditinjau dari rasanya, yang paling tidak disukai adalah proporsi herba kayu manis 5\% terhadap campuran teh hijau-stevia, formula yang lain memiliki tingkat kesukaan yang tidak beda nyata. Sedangkan dilihat dari kenampakan keseluruhan formula cengkeh $15 \%$ (S3C3) memiliki tingkat kesukaan yang sama dengan Jahe 5\% (S3J1) dan Jahe 10\% (S3J2) tetapi lebih tinggi dibanding formula yang lain.
Berdasarkan hasil tersebut, dipilih formula dengan proporsi herba $15 \%(=\mathrm{H} 3)$ untuk tahapan formulsi selanjutnya (tahap 3). Pertimbangan lain pemilihan proporsi herba $15 \%$ adalah bahwa semakin besar proporsi herba maka kapasitas antioksidan teh hasil formulasi juga semakin tinggi, mengingat salah satu peranan herba disini selain sebagai pemberi citarasa juga untuk pengkayaan antioksidan.

Formulasi tahap terakhir (tahap 3) bertujuan untuk menentukan perbandingan jahe: kayu manis: cengkeh dalam herba terpilih (S3H3 : proporsi herba 15\% terhadap teh hijau-stevia). Terdapat 10 macam perbandingan yaitu: P1 - P10 ( lihat dalam metode). Hasil analisis statistik terhadap kesukaan warna, rasa, aroma maupun kenampakan secara keseluruhan teh hasil formulasi (data tidak ditunjukkan), memperlihatkan bahwa perbandingan jahe: 
Tabel 3. Kadar Total Fenol Teh Herba Manis Formula Terpilih

\begin{tabular}{cc}
\hline $\begin{array}{c}\text { Formula teh hijau-stevia-herba dengan } \\
\left.\text { variasi komposisi herba }{ }^{*}\right)\end{array}$ & $\begin{array}{c}\text { Kadar total fenol (mg/saji) } \\
\text { 1 sajian = 1 kantong teh celup = 2 gr }\end{array}$ \\
\hline jahe:kayumanis:cengkeh $(1: 1: 0)$ & $157.73^{\mathrm{a}}$ \\
jahe:kayumanis:cengkeh $(1: 1: 2)$ & $158.27^{\mathrm{a}}$ \\
jahe:kayumanis:cengkeh $(1: 2: 1)$ & $160.87^{\mathrm{b}}$ \\
jahe:kayumanis:cengkeh $(2: 1: 1)$ & $161.40^{\mathrm{b}}$ \\
jahe:kayumanis:cengkeh $(1: 0: 1)$ & $162.67^{\mathrm{c}}$ \\
\hline Angka yang diikuti huruf yang sama menyatakan tidak berbeda nyata pada $\alpha=0.05$ \\
${ }^{*}$ proporsi teh hijau: stevia (65:35), dan herba 15\% terhadap campuran teh hijau-stevia
\end{tabular}

Tabel 4. Kalori Teh Herba Hasil Formulasi

\begin{tabular}{cc}
\hline $\begin{array}{c}\text { Formula teh hijau-stevia-herba } \\
\text { dengan variasi komposisi herba }{ }^{*}\end{array}$ & $\begin{array}{c}\text { Kalori (kal/saji) } \\
\text { 1 sajian = } \mathbf{~ k a n t o n g ~ t e h ~ c e l u p ~ = ~ 2 ~ g r ~}\end{array}$ \\
\hline Jahe:kayumanis:cengkeh(1:0:1) & $29.96^{\mathrm{a}}$ \\
Jahe:kayumanis:cengkeh(2:1:1) & $70.85^{\mathrm{b}}$ \\
Jahe:kayumanis:cengkeh(1:1:0) & $92.11^{\mathrm{c}}$ \\
Jahe:kayumanis:cengkeh(1:1:2) & $111.16^{\mathrm{d}}$ \\
\hline Angka yang diikuti huruf yang sama menyatakan tidak berbeda nyata pada $\alpha=0.05$ \\
${ }^{*)}$ proporsi teh hijau: stevia (65:35), dan herba 15\% terhadap campuran teh hijau-stevia
\end{tabular}

kayu manis: cengkeh berpengaruh terhadap kesukaan panelis terhadap warna dan rasa seduhan teh. Selanjutnya dipilih lima formula terbaik, yaitu S3H3P4 (1:1:0), S3H3P5 (1:0:1), S3H3P8 (2:1:1), S3H3P9 ( 1:2:1) dan S3H3P10 (1:1:2). Kelima formula ini selanjutnya dilakukan pengujian kadar total fenol dan kalori.

\section{Kadar Antioksidan Teh Herba Manis Formula Terpilih}

Kadar antioksidan teh herba manis lima formula terpilih ditentukan dengan pengukuran kadar total fenolnya. Pendekatan ini dilakukan karena senyawa antioksidan dalam teh hijau, jehe, cengkeh, kayu manis maupun stevia merupakan senyawa fenolik, sehingga dengan pengukuran kadar total fenol diharapkan akan mewakili kadar antioksidan total dalam teh herba hasil formulasi. Beberapa penelitian memperlihatkan bahwa kapasitas antioksidan teh hijau memiliki korelasi yang lebih tinggi dengan komponen fenolik dibanding vitamin $\mathrm{C}$, tokoferol atau beta karoten (Lee et al., 2007). Tadhani et al. (2007) meneliti tentang aktivitas antioksidan daun dan callus Stevia rebaudiana melaporkan bahwa daun stevia kering mengandung komponen fenolik total sebesar $25.18 \mathrm{mg} / \mathrm{g}$ daun (dalam berat kering), senyawa flavonoid $21.73 \mathrm{mg} / \mathrm{g}$ (dalam berat kering), dan kapasitas antioksidan total (TAC) berkisar antara 9.66 $38.24 \mathrm{mg}$ equivalent untuk ekstrak dalam air.
Tamaino, et al. (2005) menyatakan bahwa minyak atsiri kayu manis memiliki beberapa komponen fenolik seperti eugenol, cinamic aldehid dan beta caryophyllene yang berpotensi sebagai antioksidan. Winson (1997) melaporkan bahwa jahe mengandung komponen fenolik yang dikenal sebagai gingerol dan diarilhaptanoid yang mempunyai kapasitas antioksidan lebih besar dibanding vitamin $\mathrm{E}$ (alfa tokoferol).

Berdasarkan analisis statistik yang dilakukan diketahui bahwa komposisi herba berpengaruh terhadap kadar total fenol teh herba hasil formulasi. Kadar total fenol kelima formula terpilih dapat dilihat pada tabel 4

Berdasarkan tabel 3 dapat diketahui bahwa kadar total fenol tertinggi adalah pada formula dengan komposisi herba jahe: kayu manis: cengkeh (1:0:1). Adapun urutan kadar total fenol dari yang paling tinggi adalah sebagai berikut: komposisi herba jahe: kayu manis: cengkeh $(1: 0: 1)>(2: 1: 1)=(1: 2: 1)>$ $(1: 1: 2)=(1: 1: 0)$. Hal ini mengindikasikan bahwa masing-masing herba (jahe, kayu manis dan cengkeh) memiliki kontribusi yang berbeda-beda terhadap total fenol teh herba hasil formulasi dan kemungkinan terjadi interaksi antar komponen fenolik dari herba yang berbeda yang berakibat pada peningkatan ataupun penurunan total fenol yang terukur dengan metode yang digunakan dalam penelitian. Sebagai contoh, komponen fenolik formula dengan herba jahe dan 
cengkeh menunjukkan hasil pengukuran total fenol yang tertinggi sedang jahe dan kayu manis total fenolnya terendah, akan tetapi teh dengan herba jahe: kayu manis: cengkeh (1:1:2) memiliki total fenol yang lebih rendah dibanding $(1: 2: 1)$.

\section{Kalori Teh Herba Manis Formula Terpilih}

Kalori teh herba formula terpilih ditentukan dengan bomb kalorimetri. Penguhian kalori dengan bomb kalorimeter ini khusus untuk sampel dalam bentuk padat, untuk itu maka seduhan teh formula terpilih dievaporasi selanjutnya ditambahkan filler dan dikeringkan hingga diperoleh massa padat dan kering.

Hasil analisis statistik (data tidak ditunjukkan) menunjukkan bahwa masingmasing formula memiliki kalori yang berbeda nyata, hasil selengkapnya pada Tabel 3.5.

Tabel 3.4 menunjukkan bahwa semua teh herba manis hasil formulasi memiliki kalori yang sangat rendah jika dibandingkan dengan segelas teh manis dengan gula sukrosa sebagai pemanisnya. Jika untuk membuat satu gelas teh manis ditambahkan gula sebanyak 1 sendok makan ( $15 \mathrm{~g}$ ) maka kalori dari gula saja mencapai $15 \mathrm{~g}$ x 4200 $\mathrm{kal} / \mathrm{g}=6300 \mathrm{kal}$.

Kalori dalam seduhan teh herba manis ini kemungkinan berasal dari stevia, maupun herba. Menurut Komissarenko et al. (1994) ekstrak kering daun stevia mengandung flavonoid, alkaloid, klorofil dan xanthofil larut air, asam hidrosinamat ( kafeat, klorogenat, dll), oligosakarida netral yang bersifat larut air, gula, asam amino, lemak, minyak essensial dan trace elemant. Kayu manis bersifat hangat, pedas, wangi, dan sedikit manis (Anonim, 2004). Rasa manis pada kayu manis ini kemungkinan berasal dari kandungan gula didalamnya. Jahe memiliki karbohidrat yang cukup tinggi, yaitu mencapai 20 - 60\% (Nugroho et al., 1992 dan Kartasapoetra, 1996). Karbohidrat dalam bentuk pati kemungkinan ikut terekstrak pada waktu penyeduhan sedingga memberikan kontribusi pada kalori seduhan teh yang dihasilkan.
Kalori teh herba manis tertinggi pada formula dengan komposisi herba jahe: kayu manis: cengkeh (1:2:1) dan terendah pada (1:0:1), urutannya dari yang paling tinggi adalah sebagai berikut $(1: 2: 1)>(1: 1: 2)>$ $(1: 1: 0)>(2: 1: 1)>(1: 0: 1)$. Hal ini mengindikasikan bahwa jahe kurang memberikan kontribusi terhadap perbedaan kalori seduhan teh. Ini kemungkinan karena suhu dan waktu penyeduhan sama sehingga jumlah pati jahe yang mungkin ikut terekstrak juga tidak berbeda. Kayu manis dan cengkeh lebih memberikan kontribusi terhadap perbedaan kalori seduhan teh. Kayu manis memberikan kontribusi yang lebih tinggi terhadap kalori seduhan teh dibanding cengkeh, hal ini terlihat pada formula dengan perbandingan jahe: kayu manis: cengkeh $(1: 2: 1)>(1: 1: 2)$ dan kalori seduhan teh dengan formula tanpa kayu manis (1:0:1) jauh lebih kecil dibanding formula tanpa cengkeh (1:1:0).

\section{KESIMPULAN DAN SARAN}

\section{Kesimpulan}

Formula teh herba manis yang diterima oleh konsumen adalah dengan proporsi teh hijau : stevia $(65: 35)$ yaitu formula S3 dan proporsi herba $15 \%$ terhadap $\mathrm{S} 3$, dengan penggunaan herba lebih dari satu macam. Lima formula yang terpilih didasarkan pada kesukaan konsumen adalah teh herba manis dengan komposisi herba jahe: kayu manis: cengkeh (1:1:0), (1:0:1), (2:1:1), (1:2:1) dan (1:1:2). Kelima formula ini menunjukkan kadar antioksidan dan kalori yang berbeda secara signifikan. Teh herba manis formula terpilih memperlihatkan kadar antioksidan yang cukup tinggi yaitu berkisar antara $157-163$ mg fenol/ sajian. Kalori teh herba manis formula terpilih sangat rendah, yaitu berkisar antara $30-111 \mathrm{kal} / \mathrm{saji}$.

\section{Saran}

1. Teh herba manis (teh hijau-stevia-herba) ini cukup prospektif untuk dikembangkan sebagai minuman fungsional berbasis bahan lokal, untuk itu perlu dilakukan pengkajian scale up skala industri dan analisis ekonomi terhadap kemungkinan 
pengembangannya sebagai suatu unit usaha.

2. Perlu dilakukan pengujian secara in vivo dengan menggunakan hewan coba atau relawan manusia untuk mengkaji fungsionalitas teh herba manis ini.

\section{DAFTAR PUSTAKA}

Anderson, R. A., and Broadhurst, C. L. 2004. Isolation and characterization of polyphenol type-A polymers from cinnamon with insulin-like biological activity. Journal of Agricultural and Food Chemistry, 52, 65-70

Anonim, 2004. Melawan Penyakit dengan Kayu manis. http://www.pikiran akyat.com/cetak/0104/04/1003.htm

AOAC, 2003. Official Methods of Analysis of the Association of Official Analytical Chemists, $14^{\text {th }}$ ed. AOAC, Inc. Arlington, Virginia

Astuti, M. 1995. Makanan Tradisional Tempe daan Potensinya Sebagai "Radical Scavenger" dalam Proses Penuaan. Widya Karya Nasional, Kantor Men. Pangan, Jakarta

Azima, F. 2004. Kayu Manis Cegah Aterosklerosis dan Kanker. http://www.pikiranrakyat.com/cetak/0904/ 30/cakrawala/ penelitian.htm.

Berk. 1996. The Biochemistry of Food. Elsevier Scientific Publishing Company, Amsterdam

Carey, A. W., Emily D. L. 2007. Some commonly fed herbs and other functional foods in equine nutrition: A review The Veterinary Journal xxx (2007) xxx-xxx

Carper, J. 1988. The Food Pharmacy. Simon \& Schuster Ltd., Great Britain

Dorota, M., Sabine, M., Ibrahim, E. 2004. The effect of ascorbic acid on total antioxidant activity of black and green teas. Journal Food Chemistry, 88: 447451

Gates, D. 2000. "The Stevia Story: A tale of incredible sweetness \& intrigue". www.stevia.net

Ghiselli, A., Mirella, N., Baldidan, A., Scacini, C.. 1998. Antioxidant Activity of
Different Phenolics Fraction Separated from an Italian Red Wine. Jurnal Agriculture Food Chemistry, Vol 46: 361 $-367$

Gordon, M. H. 1990. Mechanism of Antioxidant Action in Vitro dalam Food Antioxidant. Elsevier Applied Science, London : 1 - 18

Green, C. L., Robbins, S. R. J., Purseglove, J. W., and Brown, E. G. 1988. Spices Vol II. Longman Scientific and Technical, New York

Grzanna, R., Lindmark, L., Frondoza, C.G. 2005. Ginger - an herbal medicinal product with broad anti-inflammatory actions. Journal of Medicinal Food, 8 : 125-132

Ilhami, G., Gungor S. I., Beidemir, S., Mahfuz, E., Irfan, K. 2004. Comparison of antioxidant activity of clove (Eugenia caryophylata Thunb) buds and lavender (Lavandula stoe chas L.), Journal Food Chemistry, 87: 393-400

Kartasapoetra, G. 1996. Budidaya Tanaman Berkhasiat Obat. PT. Rineka Cipta, Jakarta

Kinghorn, A. D., Wu, C.D., Soejarto, D. D. 2001. Stevioside. In: O’Brien Nabors, L. (Ed.), Alternative Sweeteners, third ed., revised and expanded. Dekker, New York, pp. 167-183

Koyama, E., Sakai, N., Ohri, Y., Kitazawa, K., Izawa, O., Kakegawa, K., Fujino, A., Ui, M., 2003. Absorption and metabolism of glycosidic sweeteners of stevia mixture and their aglycone, steviol, in rats and humans. Food and Chemical Toxicology 41, 875-883

Lan Su , Jun-Jie Yin , Denys Charles , Kequan Zhoua, Jeffrey Moore , Liangli (Lucy) Yu. 2007. Total phenolic contents, chelating capacities, and radicalscavenging properties of black peppercorn, nutmeg, rosehip, cinnamon and oregano leaf. Journal Food Chemistry, 100: 990-997

Lee Kwang-Geun, Shibamoto, T. 2002. Antioxidant property of aroma extract isolated from clove buds [Syzygium aromaticum (L.) Merr. Et Perry]. Food Chemistry, 74, 443-448 
Lee, Y. L., Huang, G. W., Liang, Z. C., and Mau, J. L. (2007). Antioxidant properties of three extracts from Pleurotus citrinopileatus. LWT e Food Science and Technology, 40, 823e833.

Lin Sheng-Dun, En-Hui Liu, Jeng-Leun Mau. 2008. Effect of different brewing methods on antioxidant properties of steaming green tea. Journal Food Science and Technology , 41: 1616 - 1623

Muchtadi, D. 2000. Sayur-sayuran, Sumber Serat dan Antioksidan : Mencegah Penyakit Degeneratif. Jurusan TPG IPB, Bogor

Muhlisah, F. 1999. Temu-temuan dan Empon-empon Budidaya dan Manfaatnya. Kanisius, Yogyakarta

Murcia, M. A., Egea, I., Romojaro, F., Parras, P., Jimenez, A. M., \& MartinezTome, M. 2004. Antioxidant evaluation in dessert spices compared with common food additives. Influence of irradiation procedure. Journal of Agricultural and Food Chemistry, 52, 1872-1881

Nirmala, K., Prasanna, K., Kalpagam, P. 2008. Alterations in antioxidant status of rats following intake of ginger through diet. Journal Food Chemistry 106: $991-$ 996

Nugroho, E. I., Whendrato, Suhartanto, Mandyana, I. M. dan Kusumo. 1992. Tumbuh-tumbuhan Berkhasiat Obat. Eka Offset, Semarang

Paul A. Kilmartin, Chyong F. Hsu. 2003. Characterisation of polyphenols in green, oolong, and black teas, and in coffee, using cyclic voltammetry. Journal Food Chemistry, 82: 501-512
Pokorny J., N. Yanishlieva, M. Gordon. 2001. Antioxidants in Food. CRC Press. Washington, DC

Rajesh, M., Nagarajan, A., Siddhuraju, P., Sellamuthu, M. 2008. The antioxidant activity and free radical scavenging potential of two different solvent extracts of Camellia sinensis (L.) O. Kuntz, Ficus bengalensis $\mathrm{L}$. and Ficus racemosa $\mathrm{L}$. Journal Food Chemistry, 107: 1000 1007

Stoilova, I., Krastanov, A., Stoyanova, A., Denev, P., Gargova, S. 2007. Antioxidant activity of a ginger extract (Zingiber officinale). Journal Food Chemistry, 102: 764-770

Tadhani, M.B., Patel, V.H., Rema Subhash. 2007. In vitro antioxidant activities of Stevia rebaudiana leaves and callus. Journal of Food Composition and Analysis, 20: 323-329

Tomaino, A., Cimino, F., Zimbalatti, V., Venuti V., Sulfaro, V., De Pasquale, A., Saija, A. 2005. Influence of heating on antioxidant activity and the chemical composition of some spice essential oils. Journal Food Chemistry, 89 : 549-554

Wijayakusumah, H. 1997. Tumbuhan Berkhasiat Obat Indonesia: Rempah, Rimpang dan Umbi. Milenia Populer, Jakarta

Winston, J. C., 1997. Phytochemicals: guardians of Our Health. J. Am. Diet Assoc., 97 (suppl 2): S199-S204

Yen, G. C. and Chen, H. Y. 1995. Antioxidant activity of various tea extracts in relation to their antimutagenicity. Journal of Agriculture and Food Chemistry, 47, 23-32 